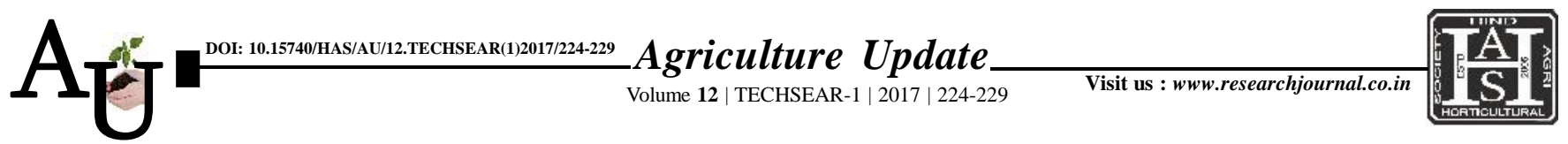

口 e ISSN-0976-6847

\title{
Research Article: Integrated weed management in cotton
}

Article Chronicle: Received :

11.07.2017;

Accepted :

26.07.2017

\section{N. MALARKODI, R. BALASUBRAMANIAN, K. BALAKRISHNAN，S. KRISHNASAMY AND N.O. GOPAL}

SUMMARY : Field experiments were conducted during 2013 and 2014, at Agricultural College and Research Institute, Madurai to study the effect of integrated weed management in rainfed cotton. The weed management practices consisted of pendimethalin $\left(1.0 \mathrm{~kg} \cdot \mathrm{ha}^{-1}\right)$ and (Calotropisgigantea leaf extract spray at three concentrations $(10 \%, 20 \%$, and $30 \%)$ in combination with power weeder operation twice and manual weeding twice. From the results of the experiments, it could be recommended that the integrated weed management practices like, application of PE pendimethalin at $1.0 \mathrm{~kg} \mathrm{ha}^{-1}+$ power weeding on 40 DAS $\left(\mathrm{T}_{11}\right)$ recorded higher seed cotton yield and economic return.

How to cite this article : Malarkodi, N., Balasubramanian, R., Balakrishnan, K., Krishnasamy, S. and Gopal, N.O. (2017). Integrated weed management in cotton. Agric. Update, 12(TECHSEAR-1) : 224-229; DOI: 10.15740/ HAS/AU/12.TECHSEAR(1)2017/224-229.

\section{KEY WoRDS:}

Weed density, Weed dry weight, Yield, Economic return

\section{Author for correspondence :}

\section{N. MALARKODI}

Agricultural College and Research Institute (T.N.A.U.), MADURAI (T.N.) INDIA

Email:malarmdu6@ gmail.com

See end of the article for authors' affiliations 